\title{
Brazilian Science and Technology Policy and the Case of Embrapa Semiarid
}

\section{Maria Clotilde Ribeiro*}

\begin{abstract}
This study focuses on Brazil's international co-operation in science and technology (S\&T), notably technical transfers to the semiarid branch of the Brazilian Agricultural Research Corporation (Embrapa) from the early 1990s onwards. It is based on interviews with Embrapa personnel, as well as literature and documentary reviews. It starts by outlining a conceptual framework. Next, it examines Brazil's Science, Technology and Innovation (STI) policy, and compares this policy and actual S\&T co-operation initiatives in order to establish whether they converge or diverge. The cooperation in question involved a diversified agenda aimed at meeting global demands, encompassing issues such as the green economy, clean and renewable energy, climate change and desertification, species extinction threats, social technologies, and biodiversity. The study shows that international collaboration in the period under review largely conformed with Brazil's STI policy. However, it identifies some gaps and areas of concern, notably a degree of fragmentation between the macro and micro levels of co-operation, which should be effectively managed if S\&T collaboration is to consolidate Brazil's international role and its geo-political interests.
\end{abstract}

Keywords: International Co-operation in Science and Technology; Science and Technology Policy; Agriculture; Innovation.

\section{Introduction}

Given the movement towards knowledge economies, competitiveness among countries increasingly depends on the generation and use of scientific knowledge, as this feeds the innovation required to create new products and processes (Foray 2006). Moreover, scientific and technological knowledge, along with innovation, are closely correlated with economic development and democratic governance.

Sebastián and Benavides (2007) emphasise that international co-operation is an intrinsic component of knowledge generation, and note that this is the basis of 'big science' in areas such as high-energy physics, space, astrophysics, genome sequencing, and nuclear fusion, given that the international dimension increases collaboration opportunities and

* Federal University of Vale do São Francisco (UNIVASF), Petrolina-PE, Brazil; clotilde.ribeiro@univasf.edu.br. 
consequently the potential of groups and institutions. All this underlines that scientific and technological co-operation plays a vital role in countries' international co-operation strategies. A good example of the growing relevance of the international dimension of scientific knowledge production is the growth of scientific co-publications in North America, Europe, Asia, Latin America and Africa, the last three on a smaller scale. One must agree with Contini and Séchet (2005), who point out that development strategies in emerging countries such as Brazil must necessarily involve strategic alliances with knowledge generation centres of excellence around the world, through initiatives such as:

formal and informal training, partnerships in joint projects and other creative forms of insertion into the world of research, such as the physical presence of senior researchers in foreign laboratories, conducting strategic research partnerships, and monitoring science and technology in their areas of expertise (Contini and Séchet 2005: 38).

Given this, they argue that scientific and technological research in Brazil needs to be internationalised, as 'isolation and exaggeratedly nationalist self-sufficiency are suicidal strategies for the country' (Contini and Séchet 2005: 38). Figure 1 reflects international scientific co-production in three of the four BRICS countries - Brazil, Russia, India and South Africa - between 1996 and 2013.

Figure 1: International scientific co-production in Brazil, Russia, India and South Africa, 1996-2013

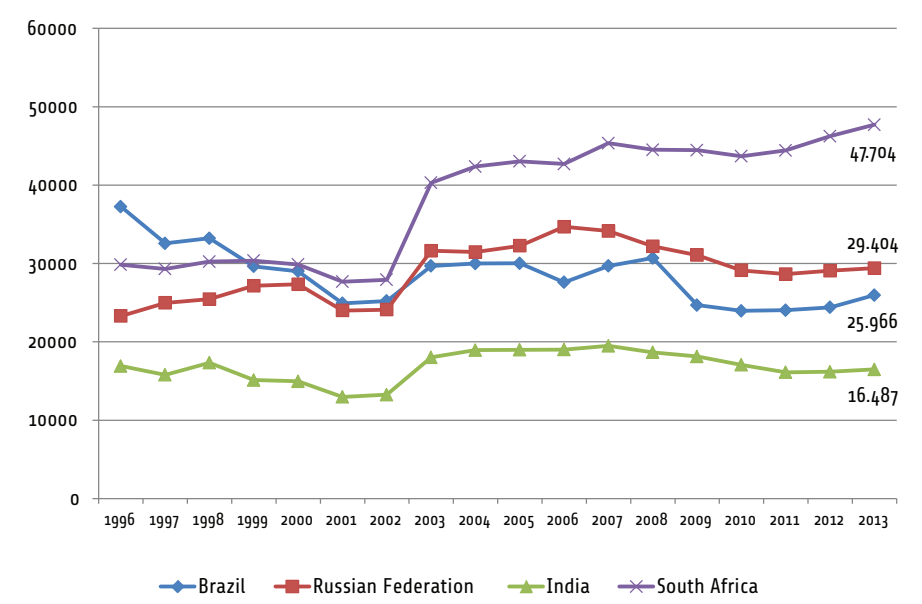

Source: Scopus Base. SJR, Scimago Journal \& Country Rank. Available at <http://www.scimagojr.com/>

Except for India, the other countries achieved higher scores than Brazil, with South Africa's score almost twice as high. Multiple factors contribute or are vital to the internationalisation of S\&T, some external, and others internal to innovation systems, understood by Lundvall (1997) as comprising elements and relationships that interact in the production, dissemination and application of knowledge. Internal factors include the increasingly interdisciplinary nature of research, the study of complex and interdependent problems, 
requirements for infrastructure and unique equipment, and research optimisation groups that require complementary skills and abilities, leading to a growth in scientific collaboration among countries, and promoting the internationalisation of S\&T. This is due not only to the current conditions under which scientific and technological development are produced, but also to the standards of international relations that currently apply, as well as economic requirements for the pursuit of socially and environmentally sustainable development models. It is in this context that the international dimension grows in weight, and become more significant to the organisation of research activities and new means of knowledge production in contemporary society.

Besides the intrinsic aspects of scientific and technological development, it also occurs in a political, economic and socio-cultural context. Co-operation in the production of knowledge and new technologies occurs in many different ways and in complex associative structures, frequently comprising different types of organisations and spanning several spheres, from the public through the NGO to the private sector. International Cooperation for Development (ICD) forms part of this form of co-operation. The author designed and conducted this study in this framework as part of her doctoral research. Some of the results are presented in this article.

This study is aimed at elucidating international co-operation in S\&T as well as research and development, including technical transfers, as experienced by Embrapa Semiárido, or the Agricultural Research Centre for Semiarid Tropics (CPATSA) in Brazil, from the 1990s onwards. This is done in an effort to understand elements of the technical-management and political-strategic order. Since its establishment in 1973, Embrapa has played a central role in Brazil's international co-operation in S\&T, and is an active recipient of the co-operation offered by Brazil to other countries. As Ribeiro (2015) has noted in her analysis of the national system of agricultural research, Embrapa is the central node of a tangle of relationships between Brazilian institutions and a range of international organisations.

More specifically, this study examines the degree to which CPATSA's international collaboration conformed to Brazil's Science and Technology Policy (STP) over the past three decades. All the joint initiatives undertaken in collaboration with international entities were examined, and classified into central or governmental initiatives, whether via bilateral or multilateral organisations or intergovernmental networks, and decentralised initiatives, undertaken by non-state organisations only.

CPATSA's main initiatives were mapped via documentary and literature research, as well as two sets of interviews with key personnel, conducted from March 2013 to January 2015. The exploratory interviews were conducted with nearly all active members of the research unit (98\%, corresponding to 80 researchers) and all its managers (four), thereby seeking to identify those who had experienced international co-operation initiatives, considering both the category stricto sensu and that of S\&T co-operation for development (46\%).

The second set of interviews deepened an understanding of the initiatives identified in the previous step by those who had participated in them ( $46 \%$ of staff, equal to 38 researchers). The interviews were conducted at the CPATSA centre in the lower basin of the São Francisco River, which is located in the countryside of the state of Pernambuco (42 $\mathrm{km}$ from the municipality seat of the city of Petrolina). 
Interviews were also conducted with key Embrapa Semiárido stakeholders, notably a local politician involved in the development of the São Francisco Valley, and heads of international organisations who have worked and still work with CPATSA, namely CIRAD, INRA and CGIAR. ${ }^{2}$

The documentary research was conducted in Embrapa Semiárido's repository, also situated in its research centre, and involved a search for agreements and contracts between Embrapa and international institutions; annual activity reports; researchers' international travel reports; final reports on the implementation of international co-operation projects; and institutional pamphlets and newspapers, all published in the relevant period. Surveys were also conducted in other electronic databases made available by Embrapa, focusing on the scientific production of the semiarid unit.

Given that this research has focused on CPATSA researchers, the field has been left open for further work, this time focusing on farmers. New research can assess the concrete results obtained by them, whether the objectives of the cooperative programmes in question were achieved, and if so, to what degree. Among other things, new studies can indicate if the actual results and consequences of projects diverge from the stated objectives, and if they even surpass them or work in the opposite direction.

\section{S\&T in Brazil's agricultural sector}

There is now strong evidence that current major problems facing our planet today relate direct or indirectly to the agriculture sector. Issues such as climate change, desertification, food security, and scarcity of natural resources, among others, require a prompt transformation of the agriculture sector into a more dynamic, competitive, and responsiveto-strategic-demands sector. This is due to profound changes worldwide, related to environmental issues as well as structural changes in the global food and agribusiness sector. ${ }^{3}$ These include the integration of agriculture into global markets; the transformation of consumers into active players in the processes of technological change, especially aimed at food security (Tribe 1994; Chaves 2010); and the growth of private investment in new technologies, including information and communication technologies. While the growing demand for food and energy and changes in consumer behaviour have emerged as key factors in the agricultural sector, the global integration of agricultural markets, supply chains and communications systems have created new opportunities for the sharing of goods, services, and ideas between consumers, producers, scientists, and business environments, in a highly dynamic situation.

Chaves (2010) points out that this panorama is accompanied by advances and discoveries in areas such as microbiology, genomics, nanotechnology, bioinformatics and other scientific fields, with the potential to change the quantity and quality of food and agricultural products.

Agribusiness plays a major role in the Brazilian economy, contributing 1,092,237.71 million BRL to the economy in 2013, amounting to $22.54 \%$ of GDP, if suppliers, producers and distributors are included (Cepea/USP; IBGE). ${ }^{4}$ This shift over the past 35 years, 
during which the country developed from a vegetable importer to the world's largest food exporter, is due to investment in research, development and innovation (RDI) in agricultural sciences, which led to the vigorous development of the agricultural sector and a prominent role for agribusiness in economic and social development, as outlined by many authors (Cruvine and Martin-Neto 1999; Chaves 2010; Contini 2010; Rezende 2011). This led to the sustained provision of food to a growing urban population, as well as raw materials and biofuels to industry, at decreasing costs. It also drove the input industry, the processing industry, and service provision.

A milestone on the way from food dependency to major food exporter was the establishment of the Brazilian Agricultural Research Corporation (Embrapa) in 1973. Chaves (2010) points out that an innovative element of its political/administrative focus is the adoption of international co-operation as an innovation policy for agribusiness, which seeks sustainability in research by building trust at the inter-organisational and international level.

In this context, international co-operation in S\&T assumes a strategic role that should be regarded as a priority for researchers and decision-makers. International co-operation in S\&T is a driver of agricultural development, particularly in developing countries. Moreover, issues of pressing relevance to humanity are directly related to agriculture, and rely on science and new technologies to mitigate major problems such as global climate change, food security, and the search for renewable energy. One can even say that the success of R\&D in agriculture today depends on international collaboration, and the impact of $R \& D$ in this sector depends on how these multiple and different agents work together, from project design to monitoring and evaluation.

\section{International co-operation in S\&T: complexity, logic and types}

Science and technology were not born together, and the connection between them is the result of a long historical process. It only started in the Hellenic period, and was reinforced during the Renaissance. Studies in this area point to exponential growth in the combined roles of S\&T from then onwards, which is readily understood due to their central role in defining the conditions of human life and influencing social formations (Bazzo et al 2003). This is reflected in the increasing intrusion of S\&T into the international agenda, becoming an instrument of what Flink and Schereider (2010) describe as science diplomacy.

Sebastian and Benavides (2007) have described one of the most remarkable characteristics of knowledge production, which differentiates this from other factors of production (capital, labour, and natural and physical resources): it is an intangible asset, which yields increasingly marginal returns in the sense that its use does not destroy it for later use, but rather increases its value. We also need to take note of the complexity of S\&T co-operation, not only due to the plurality of actors, whether public, private or non-government, but also due to the different ways in which it is operationalised. These logics are distinguishable in many ways, including the objectives of relevant initiatives, the types of actors involved in processes of dialogue, and the symmetry (or asymmetry) among 
participants. This is besides the political and strategic aspects of these initiatives, and the modalities, dynamics, and organisational arrangements adopted for their achievement.

Thus S\&T co-operation can move from centralised state co-operation at the one end of the spectrum to decentralised co-operation by non-state organisations at the other, sometimes involving institutions in the knowledge production sector, such as universities and research centres. Between these two extremes are 'hybrid' arrangements involving different types of organizational structures, often combining state organizations, including multilateral (IGOs) and bilateral organizations, with market organizations and civil society from diverse backgrounds. In turn, S\&T co-operation in the state sphere can occur in the context of International Co-operation for Development (ICD), which can be defined as:

A system that articulates the policy of states and non-state actors, a set of standards disseminated (or, in some cases, prescribed) by international organizations and the belief that the promotion of development based on solidarity would be a desirable solution to the contradictions and the inequalities generated internationally by capitalism (Milani 2012: 211).

However, this form of co-operation is also not unisonous, ranging from North-South to South-South co-operation. Unlike the North-South model that assumes extreme inequalities and asymmetries between donors and recipients, South-South co-operation is based on the assumption that developing countries can and should co-operate to solve their own political, economic, and social problems, based on shared identities (Milani 2012). Besides these two models, many other innovative S\&T co-operation arrangements have emerged in the contemporary world, including trilateral North-South-South and South-South-South models, or even models involving developing countries and multilateral organisations.

The different logics guiding co-operation processes and the plurality of actors produce a diverse range of institutional arrangements, which adds to the complexity of co-operation. This is particularly true of the agricultural sector, as Hall et al (2000) have noted, due to its vast number of interfaces, the increasingly dynamic and strategic character of political agendas in respect of agriculture, and the research that must be undertaken to address them. This is without mentioning the complexity of integrating multiple sets of agendas, often in conflict with one another, with national policy-makers having to choose between serving the business needs of the agricultural sector or the interests of society. Hall et al emphasise the growth in current concerns, given a greater awareness of the need to operate in a development framework so that agricultural science help to reduce poverty, which implies dealing with this not just in terms of food supply, but also in terms of the complex social and economic factors that sustain it, leading to the need to restructure agricultural research systems in order to better meet political agendas.

It is this complexity of the institutional arrangements for agricultural research that led Hall et al (2000) to recommend a National System of Innovation (NSI) approach to conducting research in this sector. NSI is understood as a social system in which learning 
is the principal activity (Lundvall 1997). It is also seen as comprising elements and relationships that interact in the production, distribution, and use of knowledge. According to Hall et al (2000), this approach allows one to see the sector holistically and to consider a broad range of institutional forms that make up the agricultural research system. Thus, it presents advantages in the creation of a policy framework aimed at promoting co-operation agreements for agricultural research, also due to the frequent necessity of institutional changes that this system faces.

As Mintzberg (2004) has pointed out, many of the pitfalls in international co-operation that hamper or prevent effective planning occur in co-operative processes among nations, which is hardly surprising, considering the plurality and the diversity of actors at work in them. One can easily identify their multiple values: the difficulty of reconciling goals; the tendency to reduce strategies to their most basic elements, far from a rich and integrated perception of what can be done; the narrow form of rationality that planning represents, distant from intuition, creativity, and other forms of human expression; resistance to change; and the facility and tendency to develop short-term goals, far removed from long-term goals relating to quality, innovation, and effective social needs. Mintzberg's lessons and warnings may be difficult to accept, especially by a nation used to dominant programmes, resources and knowledge, or a nation whose political process gives too much weight to domestic interests or uncertain long-term commitments. If they fail to heed these warnings and improve their political process, their attempts at international co-operation will fail. That is, international co-operation can be efficient and productive, or can become a costly or even dangerous impediment as Skolnikoff (1993) has indicated.

Troyjo (2003) identifies three types of international co-operation, namely scientific-technological, technical, and educational. The first category typically comprises programmes or projects involving equivalent technical and scientific expertise from the participants, often intended to go beyond the transfer of knowledge to understanding innovation for economic development. Knowledge is altered significantly, and there is a balance between the motives for co-operation and political-diplomatic objectives. Technical co-operation has welfare characteristics, and 'denotes a process in which a simple transfer makes knowledge, expertise, equipment, human resources etc. available to less-developed agent, allowing for leaps forward in the search for training. Ideally, it aims to level out the quality of research and international production in a specific area without necessarily increasing the stock of knowledge, because there is no concern with innovation. Educational co-operation is a particular case of technical co-operation.

Despite the boundaries between these types of co-operation, several authors, notably Troyjo (2003) and Sebastian and Benevides (2007), regard the equivalence of technical and scientific competence as the distinguishing parameter, with the latter adding bidirectionality and complementary capabilities to the objectives of S\&T co-operation stricto sen$s u$. These authors also stress that joint research and the goal of knowledge generation are present in both types of co-operation. According to them, S\&T co-operation stricto sensu occurs between countries with high levels of scientific and technological development, and is characterised as co-operation between pairs exhibiting a high degree of symmetry, and objectives that are basically scientific and technological. In addition, they highlight 
the input of NGOs as actors and as agents promoting S\&T co-operation for development, stressing their importance in the diffusion and adoption of technologies.

In turn, Quiñones and Tezanos (2011) and Quiñones (2013) stress that the creation of National Systems of Innovation (NSI) and the recovery of local technological knowledge (Table 1) are among the objectives of this type of co-operation, given that donors are able to help developing countries recover autochthonous knowledge produced in their own locus. As regards the subtleties that distinguish international S\&T co-operation from technical co-operation, it should be noted that the vision which adopts the innovative character of initiatives as a differentiating element does not deny that the transferred technologies, possessed by the donors, can be innovative from the point of view of the recipient. This category, named of 'soft innovation' by the OECD (2005), is able to produce advances in the country that introduces them, despite not being innovative from the donor's point of view. Technology here is seen not only as physical but also as intangible assets, such as information and learning. As Troyjo (2003) has noted, while initiatives involving knowledge production may be jointly defined and agreed, they lend themselves to diverse interpretations and appropriations, and therefore to different scientific-technological, political, economic and social gains in the co-operating countries.

Table 1: Brazil's STI / S\&T policy

\begin{tabular}{|c|c|c|}
\hline 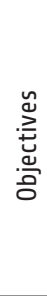 & $\begin{array}{l}1 . \\
2 . \\
3 . \\
4 . \\
5 . \\
6 . \\
7 . \\
8 . \\
9 .\end{array}$ & $\begin{array}{l}\text { Create solid National Innovation Systems (NIS) } \\
\text { Transfer knowledge and technology } \\
\text { Educate and train human resources } \\
\text { Facilitate researchers' mobility } \\
\text { Facilitate the learning of technology } \\
\text { Create RDI infrastructure } \\
\text { Sensitise society as a whole to the relevance of STI } \\
\text { Satisfy the national demand for innovation } \\
\text { Recover local technological knowledge }\end{array}$ \\
\hline \begin{tabular}{l} 
号 \\
\multirow{2}{*}{}
\end{tabular} & & $\begin{array}{l}\text { Governments } \\
\text { Multilateral organisations } \\
\text { Universities and research centres } \\
\text { National RDI organisations } \\
\text { NGOs }\end{array}$ \\
\hline 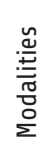 & $\begin{array}{l}1 . \\
2 .\end{array}$ & $\begin{array}{l}\text { Aids for research and technological development (agriculture, fisheries, forestry, } \\
\text { education, health, energy and the environment) } \\
\text { Aid for the acquisition of advanced and specific competencies (professional formation, } \\
\text { higher education, statistical training, rural extension, and various forms of education } \\
\text { and formation relative to the social, productive and commercial sectors) }\end{array}$ \\
\hline
\end{tabular}

Source: Adapted from Quiñones e Tezanos (2011).

Nevertheless, Baiardi and Ribeiro (2011) emphasise that international S\&T co-operation is a key instrument for promoting autochthonous knowledge generation, and that all nation-states should seek to promote them politically. They add that it also benefits the federal and sub-federal levels, because it stimulates research and enhances innovation, thus adding a new dynamism to production chains. 


\section{International relations and S\&T: a theoretical gap}

The role of S\&T in international relations (IR) theory should be considered. Flink and Schreiterer (2010) argue that, until recently, S\&T attracted very little attention from traditional IR scholars. Very few examined its role in and contribution to international affairs, and most did so only in relatively superficial terms. The authors believe this gap may be caused by the fact that S\&T and IR scholars have very different interests, mental maps, and methods, which are difficult to reconcile. They add that S\&T does not fit well into IR theory, despite - or perhaps because - of the fact that can also be used by neorealist, neoliberal or constructivist approaches.

Dealing with the impact of S\&T on the evolution of international affairs, Skolnikoff (1993) agrees with Flink and Schreiterer (2010), stressing that few studies seek to explore this issue in any depth, and noting that IR scholars tend to treat S\&T as a given, or a 'black box'. As a result, these variables are treated as static rather than dynamic, leading to a tendency to examine only fragments of how technological change affects (or does not affect) various theoretical approaches. In his view, S\&T, or, more accurately, the development and application of technology, do not prompt direct changes in the international political system or society. Rather, they only have a gradual impact on social structures, and only affect structural factors via political and economic actors, beginning with the choices they make and continuing with accumulated social responses, and not simply because of new scientific or technological knowledge.

In another study, Skolnikoff (1977) cites five ways in which technology impacts on the international system: interdependence, the meaning of war, new patterns of interaction with new dominant societies, the development of new economic classes, and the process of internal policy. However, even if technology has evolved substantially, he argues that this has not affected most of the basic pillars of IR, or at least left the extent of its impact undetermined or ambiguous. In a later study, he affirms that the few fundamental changes are related to the impacts of nuclear weapons on military power, the effects of information technologies on centralised political power, and the competitiveness of centralised economic structures.

After analysing issues surrounding sovereignty, competition and dependence, military force and nuclear weapons, as well as the quality of governance and other geopolitical factors, Skolnikoff (1993) concludes that the international system evolving in a context of technological change can be accommodated within the realist, neorealist and liberal traditions. Realists regard states as unitary actors in an anarchic system, with power as the fundamental ordering principle, and sovereign states seeking to maximize their influence and power. Neorealists regard international regimes as a means for sovereign states to achieve their objectives in an interdependent world. Liberals, in turn, design a complex web of interdependent relationships coexisting with independent relationships and, to a considerable extent, independent of relations among states.

Skolnikoff adds that companies active in S\&T produce results that are not necessarily sought by states, but will affect their power and influence. He stresses that the international system can be accommodated within various theoretical constructs, even though many 
of its aspects have changed and continue to change, and some long-standing concepts have been affected. Nevertheless, he argues that the current international system seems certain to have developed in this way, whatever theoretical paradigm is used to describe it.

Skolnikoff (1993) notes that the various impacts of technological change form a mosaic in which the realist model of interlational relations is becoming increasingly anachronistic and incompatible with current reality. However, trends influenced by S\&T could continue to support realist theoretical constructs, notably in respect of sovereignty and military power.

While technological advances may have worked to constrain sovereignty by encouraging the rise of NGOS and global integration, it remains the organising principle of the international system, and S\&T also offers a long menu of options for states to retain and even increase their power over competing institutions. In turn, military power, long regarded as the main determinant of the power and influence of states, can no longer protect states armed with nuclear weapons. Thus the dominant role of military power in relations among industrialised states has changed greatly in favour of other sources of power and influence. However, military power is still relevant as a deterrent and a means of intimidation, and continues to play its traditional role in international relations (outside of nuclear confrontation), supported by continued progression and the spread of conventional weapons throughout the world.

Skolnikoff (1993) notes that other elements could be included in his analysis, but none of them would disprove the proposition that states remain the dominant structural element in IR. Military, economic, and social changes clearly stimulated or enabled by S\&T would neither undermine nor strongly support the main paradigms of IR theory, notwithstanding the consideration that they are far more consistent with the liberal perspective than with the realistic one. However, he emphasises that his analysis focuses only on the present and a few decades into the future, and warns that the international system may need to be reformulated to the extent that new developments related to S\&T will come to challenge current thinking more fundamentally, requiring, for example, a level of co-operation inconsistent with independent states.

\section{Modalities and instruments of international co-operation}

Bilateral and multilateral co-operation are central methods of international co-operation (Figure 2). Bilateral co-operation occurs when governments provide other states with aid through their official agencies. Multilateral co-operation occurs when aid is provided by international organisations active in development, that is, via intergovernmental agencies. Triangular or trilateral co-operation occurs when two countries (or one country and an international organisation) undertake initiatives in a third country, usually a developing country.

In the grey area between bilateral and multilateral aid are hybrid forms, including bilateral aid to regional organisations, and bilateral aid for multilateral programmes (eloquently called 'multi-bi' aid). The co-operation provided by non-governmental development organisations (NGDOs) is implemented by non-public entities, including non-clas- 
sical governmental organisations, as well as foundations and other actors in civil society and the private sector. Finally, in decentralised co-operation, the actors are subnational or sub-state entities that do not form part of the central state administration (municipalities, provinces, regions or educational institutions), and undertake international co-operation initiatives for development.

Figure 2: Modalities of international co-operation

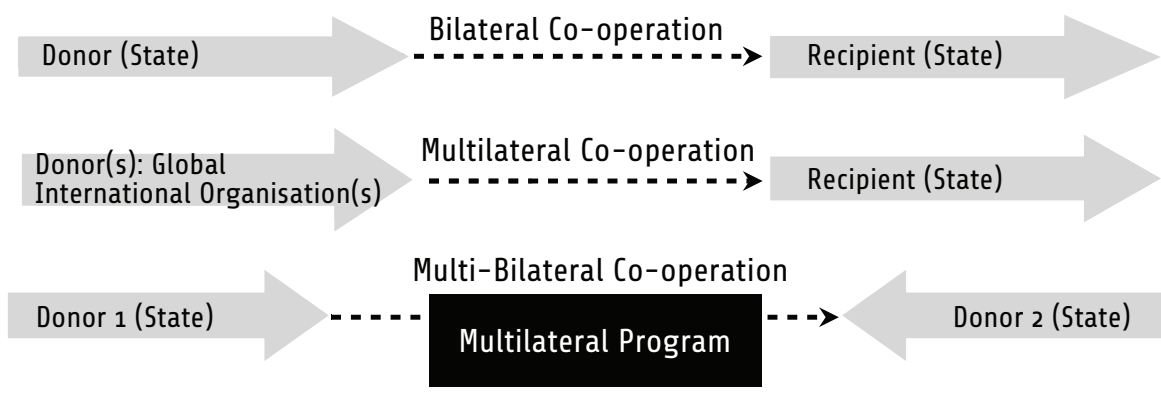

Source: Elaborated by the author, based on literature review.

While bilateral aid tends to be driven by narrower political priorities, multilateral assistance is primarily driven by global considerations. There are also differences between the multilateral co-operation provided by different actors, with the UN system, the World Bank, and the European Union playing very different roles in the international arena. UN agencies rely largely on voluntary contributions, which creates a higher degree of volatility as well as higher levels of dependence on donor countries. Sotillo (2011) notes that, in recent years, donors have increasingly committed conditional funding to specific programmes or geographic areas, through what he calls 'multi-bilateral' contributions.

In the case of triangular co-operation, a donor country (or organisation) assists a recipient country - usually a country in the process of development - to establish linkages with a second donor country, with one donor playing a lead role in channelling resources. Often, one donor country acts as a bridge to the recipient, due to a greater affinity between them in socio-cultural and often political terms. Various forms of triangular co-operation are becoming increasingly common, among others in South-South models of co-operation, where diverse relationships are being forged in innovative ways.

Sotillo (2011) emphasises that the complexity of the problems as yet to be addressed by co-operation requires different approaches and instruments, making it impossible to identify or prescribe a single instrument or method. Various interventions are classified as 'aid programmes' or 'programme-based approaches'. However, there is no agreement yet about how the latter should be defined. Lastly, the methods and instruments for international co-operation also include grants to NGOs for developmental purposes, as well as public-private partnerships for development. 


\section{CPATSA initiatives and STI policy: a preliminary overview}

In the course of classifying international initiatives mentioned by respondents (in terms of knowledge produced, technology transferred, and benefits produced), two broad types emerged, namely free-standing and structural initiatives (including central and decentralised participation). Free-standing initiatives were typically projects implemented in a closed cycle and within a limited period, typically between two and four years. Structural initiatives usually lasted for longer periods, and built stronger bonds between the participants, often paving the way to further co-operation. Modalities included multilateral, bilateral, multi-bilateral, networks, hybrid decentralised (combining different types of organisations), and decentralised academic co-operation.

The results of the research intersect with the objectives and strategic priorities of Brazil's national STI policy for 2012-2015 (Figure 2), as recorded in the document National Strategy for S\&T\&I 2012-2015 (ENCTI), published by the Ministry of Science, Technology and Innovation (MCTI) in 2012. Generally, ENCTI strongly emphasises initiatives aimed at mitigating the effects of climate change and contributing to biodiversity, accompanied by research aimed at the preservation of natural resources, which clearly converges with international co-operation received by CPATSA.

Figure 3: Strategic map of ENCTI, 2012-2015

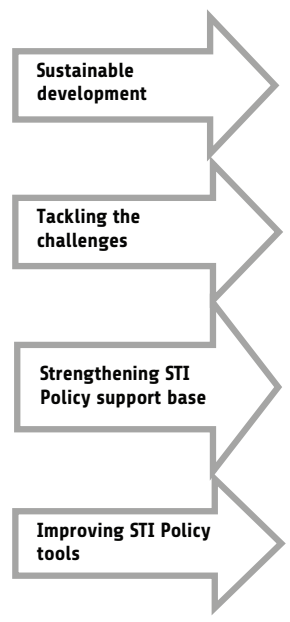

\begin{tabular}{|c|c|c|c|c|c|c|}
\hline \multicolumn{7}{|c|}{ STI as a structural axis of Brazil's development } \\
\hline $\begin{array}{c}\text { Reduce the scientific } \\
\text { and technological } \\
\text { gap between Brazil } \\
\text { and more developed } \\
\text { countries }\end{array}$ & $\begin{array}{r}\text { Expand } \\
\text { consolidate } \\
\text { leadership } \\
\text { economy of } \\
\text { knowled }\end{array}$ & $\begin{array}{l}\text { azil's } \\
\text { the } \\
\text { tural }\end{array}$ & $\begin{array}{c}\text { Enlarge the bases } \\
\text { for environmental } \\
\text { sustainability and } \\
\text { develop a low } \\
\text { carbon economy }\end{array}$ & $\begin{array}{r}\text { Cons } \\
5 \\
\text { in } \\
\text { inclu }\end{array}$ & $\begin{array}{l}\text { idate a new } \\
\text { ndard of } \\
\text { rnational } \\
\text { on for Brazil }\end{array}$ & $\begin{array}{l}\text { Overcome poverty } \\
\text { and reduce social } \\
\text { and regional } \\
\text { inequalities }\end{array}$ \\
\hline \multicolumn{2}{|c|}{ Promote Innovation } & \multicolumn{3}{|c|}{$\begin{array}{l}\text { Qualify and train } \\
\text { human resources }\end{array}$} & \multicolumn{2}{|c|}{$\begin{array}{l}\text { Strengthen research and } \\
\text { scientific and technological } \\
\text { infrastructure }\end{array}$} \\
\hline \multicolumn{2}{|c|}{$\begin{array}{l}\text { Improve the regulation mark } \\
\text { for innovation promotion }\end{array}$} & \multicolumn{3}{|c|}{$\begin{array}{l}\text { A new standard for funding } \\
\text { scientific and technological } \\
\text { development }\end{array}$} & \multicolumn{2}{|c|}{$\begin{array}{l}\text { Strengthen the National } \\
\text { System of STI }\end{array}$} \\
\hline
\end{tabular}

Source: Adapted from MCTI (2012).

Despite these convergences, which will be discussed later, the international co-operation initiatives experienced by Embrapa Semiarid did not take into account some strategic interest of Brazil's STI policy. This is due to the fact that, despite national efforts to strengthen strategic partnerships within the BRICS ${ }^{5}$ (Brazil, Russia, India, China and South Africa) alliance and within the IBSA ${ }^{6}$ (India, Brazil and South Africa) Dialogue Forum, CPATSA did not participate in any initiatives involving these countries, except for a small germplasm exchange programme with South Africa. In fact, China, India ${ }^{7}$ and Rus- 
sia were not regarded as partners at any time from 1990 until today in respect of simple projects such as the exchange programme with South Africa.

The development of Brazil's scientific, technological and innovative capacities is a vital component of its foreign policy and its role in various international jurisdictions and forums, including the strengthening of BRICS and IBSA (MCTI 2012). One cannot, however, forget the specifics of agriculture, nor the geographical and climatic peculiarities of the semiarid region under the jurisdiction of CPATSA, which could partly account for the absence of strategic partnerships developed by Embrapa Semiárido with these countries along the axis of STI in agriculture.

Given the apparent lack of concern with a strategic interest in STI policy reflected in the international co-operation initiatives involving CPTSA, starting with the challenges reflected in Figure 2, it appears that several of these initiatives converged in a search for a way to overcome these challenges. The first is the interest in expanding scientific knowledge about Brazilian ecosystems in the semiarid region and associated biodiversity, reflected in many of CPATSA's international projects.

As the Minister of Science, Technology and Innovation stated in 2012:

The Ministry of Science, Technology, and Innovation's performance regarding adding value to biodiversity was guided by the objective of increasing the scientific knowledge about Brazilian ecosystems and associated biodiversity, supporting technological development and innovation to add value to goods and services from this natural heritage. The ministry's challenge in 2012 was to plan, structure and start the implementation of strategies that permit us, simultaneously, the advancement of the knowledge of biodiversity and the identification of new molecules, products or processes of effective economic potential. The medium-term objective is to transform Brazil into an international leadership both in research on biodiversity and in sustainable applications, returning part of the profits with the sale of products or processes derived from our high species diversity, along with conservation of this immense natural heritage. ${ }^{8}$ (MCTI 2012:17) [author's translation].

Brazil's new STI strategy takes into account the STI policies of many other countries. Thus, protecting the environment and ensuring sustainable development, which includes environmental sustainability, are included in the federal guidelines. A notable international trend is the resurgence of basic science as a priority in STI policies, as it is seen as essential for the technological innovation required for sustainable development. This trend is reflected in international co-operation initiatives in which CPATSA was involved, as almost half of them were focused on basic research.

ENCTI points out that most developed and emerging countries continue to place environmental, climate, energy, food security, and water resource issues at the top of their STI agenda, in addition to health and quality of life, which remain important priorities. 
These countries encourage strategic areas and technologies, especially biotechnology, nanotechnology, health, clean energy, information and communication technology (ICT) and new materials / advanced industries. According to ENCTI, emerging economies such as the BRICS countries are emphasising the use of existing technologies and nontechnological innovation ${ }^{9}$ for meeting social needs and providing infrastructure such as water, health, education, transport and energy. This is reflected in various international co-operation initiatives involving CPATSA, aimed at meeting the needs of small farmers as well as improving rural water supplies.

While, at first glance, the STI strategies of developed countries resemble those of leading emerging countries, there are differences in emphasis and focus, as emphasised by the MCTI in the document published in 2012. Countries that already occupy advanced positions, like the USA, Germany and Japan, have targeted investment in STI in areas with great potential for future growth and at the frontiers of knowledge, such as health and green technologies, while countries that need to advance internal innovation seek to develop their national research and innovation systems, integrating their STI strategies with national development strategies. In the period under review, no international cooperation initiative involving CPATSA sought to improve Brazil's national system of research and innovation, although this is incorporated in the objectives outlined in ENCTI published in 2012 for the 2012-2015 period.

Other countries pay attention to synergies in four scientific and technological fields - nanotechnology, biotechnology, ICT, and cognitive science, particularly neuroscience under the rubric of technological convergence. In developing countries like Brazil, smallscale technologies that contribute to social inclusion and the reduction of poverty occupy a prominent position. These trends are clearly visible in CPATSA's international co-operation initiatives, with several focused on biotechnology as well as soil management and practices that increase agricultural and livestock productivity, thus converging with the interests outlined in ENCTI 2012-2015:

Farming requires a lot of research in biotechnology, soil management practices that continue to increase the productivity of agriculture and livestock in a manner consistent with the preservation of the environmental heritage. There is a growing demand for food in the world and Brazil is the country that most increased the surplus of food exports in the last decade ${ }^{10}$ (MCTI 2011:35) [author's translation].

ENCTI identifies some priority programmes in areas regarded as important for boosting the Brazilian economy, including areas related to the green economy ${ }^{11}$ and to social development. It also points out the need to promote green chemistry and develop a lowcarbon economy, emphasising growing concerns about sustainable development and the social effects of global warming. Thus, it stresses the growing need to develop technologies that will contribute to building a greener and more sustainable economy. In this sense, international co-operation initiatives involving CPATSA showed a clear adherence to Na- 
tional STI policy in respect of a green economy, social development, green chemistry, and a low-carbon economy.

\section{CPATSA and the PST: convergences or disagreements?}

This section summarises the convergences among the 51 mapped CPATSA initiatives involving international co-operation (30 with state participation and 21 decentralised) and the current ENCTI for 2012-15. The results of the research are encouraging, because it shows that 23 of these initiatives, amounting to $45 \%$, converged with the objectives and strategies of the Brazilian government (see Table 2).

Table 2: Convergence between CPATSA initiatives and ENCTI goals

\begin{tabular}{lll}
\hline GOALS & $\begin{array}{l}\text { Number of convergent } \\
\text { initiatives }\end{array}$ & \% of total \\
\hline $\begin{array}{l}\text { Consolidate the scientific-technological base for the } \\
\text { transition to a green economy, and promote innovation } \\
\text { in clean and renewable energy, biotechnology, } \\
\text { biodiversity, and climate change } \\
\begin{array}{l}\text { Develop technologies for production chains of biofuels } \\
\text { and other renewable energy sources }\end{array}\end{array}$ & $4 \%$ \\
\hline $\begin{array}{l}\text { Increase the responsiveness to the challenges and } \\
\text { opportunities associated with climate change }\end{array}$ & 4 & $17 \%$ \\
\hline $\begin{array}{l}\text { Increase scientific knowledge of Brazilian ecosystems } \\
\text { and associated biodiversity, support technological } \\
\text { development and innovation, and add value to goods } \\
\text { and services derived from these resources }\end{array}$ & 8 & $35 \%$ \\
\hline $\begin{array}{l}\text { Develop and implement social technology, and promote } \\
\text { technological extension for productive and social } \\
\text { inclusion }\end{array}$ & 10 & $43 \%$ \\
\hline \begin{tabular}{l} 
TOTAL \\
\hline
\end{tabular} & 23 & $100 \%$ \\
\hline
\end{tabular}

Source: Compiled by the author, based on field research and ENCTI (2012)

The most prominent objectives in Brazil's STI Policy were to 'develop and implement social technology, and promote technological extension for productive and social inclusion', which accounted for more than $40 \%$ of the initiatives, followed by 'increasing the scientific knowledge of Brazilian ecosystems and associated biodiversity, and supporting technological development and innovation' which accounted for $35 \%$ of the international initiatives.

The goal of 'increasing the responsiveness to the challenges and opportunities associated with climate change' was reflected in $17 \%$ of the initiatives, while the transition to a green economy and innovation in renewable energy was reflected in only one.

The multilateral modality accounted for almost $50 \%$ of converging initiatives (see Table 3 and Figure 4). By contrast, network initiatives displayed low levels of convergence with Brazilian STI policies, which stems from the fact that many of them were focused on fostering linkages among international research centres aimed at generating new research 
or transferring technologies. The stronger convergence of multilateral initiatives with ENCTI goals can be explained by two factors. The first is that most initiatives involving Embrapa Semiárido featured multilateral participation. The second is that ENCTI itself reflects a growing adoption of international trends in S\&T.

Table 3: Convergence between CPATSA initiatives and ENCTI goals by modality

\begin{tabular}{|c|c|c|c|c|c|c|c|}
\hline GOALS & $\begin{array}{l}\text { Multi } \\
\text { lateral }\end{array}$ & Bilateral & Network & Hybrid & $\begin{array}{l}\text { Decen } \\
\text { tralised }\end{array}$ & $\begin{array}{l}\text { Number } \\
\text { of con- } \\
\text { vergent } \\
\text { initia- } \\
\text { tives }\end{array}$ & $\%$ \\
\hline $\begin{array}{l}\text { Consolidate the scientific- } \\
\text { technological base for the } \\
\text { transition to a green economy, and } \\
\text { promote innovation in clean and } \\
\text { renewable energy, biotechnology, } \\
\text { biodiversity and climate change } \\
\text { Develop technologies for production } \\
\text { chains of biofuels and other } \\
\text { renewable energy sources }\end{array}$ & 1 & 0 & 0 & 0 & 0 & 1 & $4 \%$ \\
\hline $\begin{array}{l}\text { Increase responsiveness to the } \\
\text { challenges and opportunities } \\
\text { associated with climate change }\end{array}$ & 1 & 1 & 0 & 0 & 2 & 4 & $17 \%$ \\
\hline $\begin{array}{l}\text { Increase scientific knowledge of } \\
\text { Brazilian ecosystems and associated } \\
\text { biodiversity, support technological } \\
\text { development and innovation, and } \\
\text { add value to goods and services } \\
\text { derived from these resources }\end{array}$ & 2 & 2 & 1 & 1 & 2 & 8 & $35 \%$ \\
\hline $\begin{array}{l}\text { Develop and implement social } \\
\text { technology, and promote } \\
\text { technological extension for } \\
\text { productive and social inclusion }\end{array}$ & 7 & 1 & 0 & 2 & 0 & 10 & $43 \%$ \\
\hline TOTAL & 11 & 4 & 1 & 3 & 4 & 23 & $100 \%$ \\
\hline
\end{tabular}

Source: Compiled by the author, based on field research and ENCTI (2012).

Figure 4: International S\&T initiatives involving CPTSA by modality

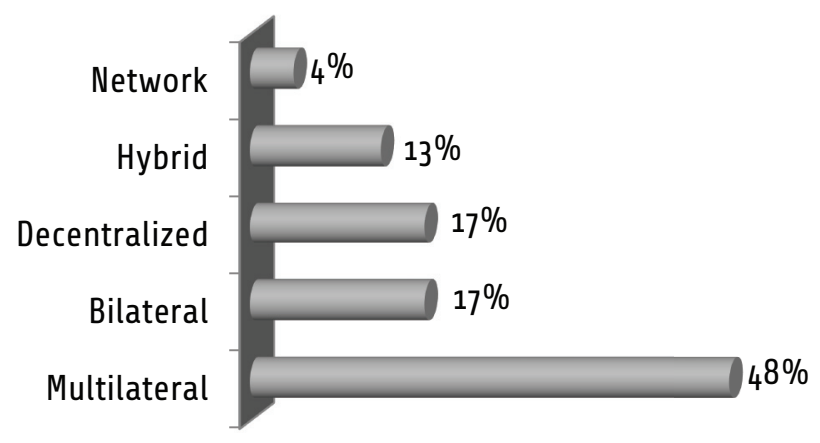


The fourth ENCTI goal, which was aimed at the development and application of social technologies, displayed the highest level of convergence (10), seven in the multilateral modality, oriented towards family farmers, in line with the development of territories, identities, and participatory methodologies as well as programmes and projects for developing food and nutrition security.

Table 4: Convergence between international co-operation and STI policy (goal 1)

\begin{tabular}{l} 
Goals \\
\hline Consolidate the scientific-technological base for the transition to a green economy, and promote innova- \\
tion in clean and renewable energy, biotechnology, biodiversity and climate change \\
Develop technologies for production chains of biofuels and other renewable energy sources, focusing on \\
diversifying and preserving their roles in the Brazilian energy matrix
\end{tabular}

Strategies

Develop new technology Support industrial technological innofor the diversification of raw material in the production of biodiesel vation in parts, pieces and systems for hydroelectricity and solar, wind, and biomass energy
Develop technologies for increasing energy security and innovation in energy efficiency, associated with the transmission of electric energy and intelligent energy networks

\section{Convergent initiatives}

JATROPT Project: Research aimed at improving Jatropha curcas for the Multilateral production of biodiesel, funded by the EU

Source: Compiled by the author, based on field research and ENCTI (2012).

The second highest level of convergence between international co-operation and ENCTI goals was in the area of expanding scientific knowledge of Brazilian ecosystems and associated biodiversity, focusing on innovation aimed at adding value to goods and services derived from these resources, which featured eight initiatives distributed in various modalities. Tables 4 to 7 reflect each of the four ENCTI goals plus associated strategies, as well as the nature and modality of convergent initiatives.

The attempt to consolidate a scientific and technological basis for the transition to a green economy and the promoting of innovation in the direction of clean energy (goal number 1) was reflected in just one co-operative effort (Table 4). This was the JATROPT project funded by the EU, aimed at identifying and selecting the best species of Jatropha curcas for producing biodiesel. Nevertheless, given that the green economy cannot be provided with a technological base without a sustainable agricultural production sector, this broad goal was present indirectly in several initiatives, going beyond the interest in diversification and in efficient energy, and also emphasising biotechnology, biodiversity, and the effects of climate change.

As is well known, Brazil needs to diversify its sources of energy. Moreover, the growing international movement towards climate change mitigation requires the development of low-carbon technologies. In the wider area of knowledge involving bio-energy, liquid biofuels stand out in Brazil, and ENCTI emphasises that the increase in demand for energy in the coming years highlights the need for investment in the technological development 
of these fuels. Another aspect to highlight is the convergence between ENCTI goals and the exchange of germplasm with different countries, an initiative aimed at building Brazil's germplasm bank and solving existing agricultural problems. These initiatives conform with the national strategy for consolidating the network of Biological Resource Centres ${ }^{12}$ and the Brazilian Centre of Biological Materials, which are linked to the national objective of developing innovative biotechnologies.

Mitigating climate change constituted an important goal in ENCTI (2012-2015), as shown in Table 5. The document stresses that sustainable development in Brazil is closely linked to the opportunities and challenges associated with climate change. It warns, however, that Brazil's large size and geographic features create difficulties in monitoring climate and hydro meteorological phenomena capable of producing large-scale damage. For instance, it is difficult to map areas with a higher potential for natural disasters, which is essential for detecting early signs of or potential trends in climate change, and formulating adaptation and mitigation strategies.

Table 5: Convergence between international co-operation and STI policy (goal 2)

\begin{tabular}{|c|c|}
\hline \multicolumn{2}{|c|}{ Goal } \\
\hline \multicolumn{2}{|c|}{ Increase responsiveness to the challenges and opportunities associated with climate change } \\
\hline \multicolumn{2}{|c|}{ Strategies } \\
\hline Monitor and observe the impacts of climate change & $\begin{array}{l}\text { Develop technology and innovation to address } \\
\text { the effects of climate change }\end{array}$ \\
\hline \multicolumn{2}{|c|}{ Convergent initiatives } \\
\hline $\begin{array}{l}\text { Research about seed stress due to climate change in } \\
\text { co-operation with the Kew Botanical Garden }\end{array}$ & Bilateral \\
\hline $\begin{array}{l}\text { DesertWatch Project for the study of deforestation via } \\
\text { satellite images from the European Space Agency. } \\
\text { Pilot areas: Brazil (north east), Mozambique, and } \\
\text { Portugal, in co-operation with UNCCD (interrupted) }\end{array}$ & Multilateral \\
\hline $\begin{array}{l}\text { Research project in co-operation with MIT (USA) to } \\
\text { assess the emission of greenhouse gases in animal } \\
\text { production systems }\end{array}$ & Decentralised \\
\hline $\begin{array}{l}\text { Research in co-operation with INTA (Argentina) about } \\
\text { the impact of climate change on diseases and pests in } \\
\text { crops of agroindustrial importance to Argentina and } \\
\text { Brazil }\end{array}$ & Decentralised \\
\hline
\end{tabular}

Source: Compiled by the author, based on field research and ENCTI (2012)

The study also points to the absence of environmental observation systems in Brazil for detecting the impacts of climate change, which increases its vulnerability to climate change. In this respect, the national STI strategy proposes to create a system for observing the impacts of climate change, and draws attention to Brazil's lack of an efficient system of environmental information that would support risk management in respect of natural disasters, or the forecasting of natural disasters in vulnerable areas. Some convergent initiatives were mapped, one of which is still ongoing in the bilateral decentralised mode 
with the English state organisation Kew Botanical Garden as donor, and the other a multilateral initiative involving the UN body for combating desertification (UNCCD) and the European Space Agency (ESA).

The collaboration with Kew is focused on understanding the stress suffered by seeds as a result of climate change, while the UNCCD aimed to study deforestation areas using satellite images from the ESA. However, this project was not completed. Two other decentralised initiatives were identified: an ongoing project involving the Massachusetts Institute of Technology (MIT), aimed at assessing the emission of greenhouse gases in animal production systems; and the other, a project involving the National Institute of Agricultural Technology of Argentina, aimed at assessing the impact of climate change on diseases and pests affecting crops of interest to both countries.

ENCTI's goal involving biodiversity and ecosystems emphasises innovation based on biodiversity, information management, the public availability of data, and training of human resources and institutions. Eight initiatives were found to adhere to these goals, via various modalities (Table 6).

The state sphere includes a multilateral research initiative funded by the World Bank which emphasises biodiversity for increased productivity, as well as two bilateral initiatives: one a horizontal South-South initiative between Brazil and Venezuela, aimed at exchanging genetic material in order to combat a pest common to both countries, and another by a unilateral donation of germplasm by the US Department of Agriculture for the assembly of a germplasm bank at CPATSA.

The decentralised modality included two initiatives involving universities in countries in an advanced stage of scientific and technological development (USA and Netherlands), and one in the reticular mode, via the CYTED ${ }^{13}$ network.

One of these, with the University of Michigan, involved seeking new uses of biodiversity in semiarid regions, and the other, with the Dutch University of Wageningen, involved the conservation and use of genetic resources. Therefore, the goal of increasing scientific knowledge of Brazilian ecosystems and associated biodiversity is evident in many of the mapped CPATSA initiatives, in co-operation with various institutions such as the EU, the World Bank and the CYTED network, as well as decentralised initiatives (35\% of the 23 initiatives that converge with ENCTI).

As regards ENCTI's fourth goal, it was found that interest in the development and application of social technologies for productive and social inclusion permeated most of the international co-operation initiatives received by CPATSA, with ten occurrences mapped (Table 7). These included the development of STI programmes and projects for improving food and nutrition security, and programmes for diffusing social technologies in ways that promoting the productive inclusion of entrepreneurs, notably economically sustainable micro and small enterprises.

Seven of these initiatives were multilateral; one was bilateral, with the Japan International Cooperation Agency (JICA), and two were hybrids, involving different types of organisations. One, involving the UN Food and Agriculture Organisation (FAO), and CIRAD, the French state research centre focused on agriculture and development, focused 
on territorial identities in semiarid regions, and led to a broad training programme for young farmers. Another hybrid initiative, funded by the World Bank and the Bill and Melinda Gates Foundation and supported by the multilateral programmes Harvest Plus and AgroSalud, was aimed at improving the nutritional value of food.

Table 6: Convergence between international co-operation and STI policy (goal 3)

\begin{tabular}{|c|c|}
\hline \multicolumn{2}{|l|}{ Goal } \\
\hline \multicolumn{2}{|c|}{$\begin{array}{l}\text { Increase scientific knowledge of Brazilian ecosystems and associated biodiversity, and support } \\
\text { technological development and innovation in order to add value to goods and services derived from } \\
\text { these resources }\end{array}$} \\
\hline \multicolumn{2}{|l|}{ Strategies } \\
\hline $\begin{array}{l}\text { Promote the management and valorisation of goods } \\
\text { and services derived from biodiversity and ecosystems }\end{array}$ & $\begin{array}{l}\text { Support the construction of a national } \\
\text { genome bank, in a partnership between } \\
\text { Embrapa and the Ministry of Science, } \\
\text { Technology and Innovation }\end{array}$ \\
\hline \multicolumn{2}{|c|}{ Convergent initiatives } \\
\hline $\begin{array}{l}\text { PROBI01 Project - increase production through } \\
\text { biodiversity (pollinators of passion fruit and mango), } \\
\text { with World Bank resources }\end{array}$ & Multilateral \\
\hline $\begin{array}{l}\text { Project aimed at diversifying agricultural activity in the } \\
\text { São Francisco Valley with the use of products from the } \\
\text { Valley (organic agriculture), with funding from the EC } \\
\text { and in co-operation with the University of Bologna }\end{array}$ & Hybrid \\
\hline $\begin{array}{l}\text { Project for developing bioactive ingredients based on } \\
\text { tropical, exotic, and native fruits from Latin America, } \\
\text { funded by the CYTED network }\end{array}$ & Network \\
\hline $\begin{array}{l}\text { Receipt of acerola germplasms from the USDA for the } \\
\text { assembly of a germplasm bank at CPATSA }\end{array}$ & Bilateral \\
\hline $\begin{array}{l}\text { Biodiversity survey of the semiarid region to identify } \\
\text { possible uses, in co-operation with the University } \\
\text { of Michigan (under the macro project of Embrapa } \\
\text { headquarters) }\end{array}$ & Decentralised \\
\hline $\begin{array}{l}\text { Research aimed at endangered and invasive species, } \\
\text { funded by the World Bank }\end{array}$ & Multilateral \\
\hline $\begin{array}{l}\text { Research aimed at the conservation and use of genetic } \\
\text { resources, in co-operation with the University of } \\
\text { Wageningen, and initiated by the Embrapa Genetic } \\
\text { Resources Unit (Cenargen) }\end{array}$ & Decentralised \\
\hline $\begin{array}{l}\text { Exchange with Venezuela of genetic material of Psidium } \\
\text { sp, aimed at solving a common problem by introducing } \\
\text { a germplasm of guava trees resistant to Meloidogyne } \\
\text { mayaguensis }\end{array}$ & Multilateral (S-ऽ) \\
\hline
\end{tabular}

Source: Compiled by the author, based on field research and ENCTI (2012) 


\section{Goal}

Develop and implement social technologies, and promote technological extension for productive and social inclusion

\begin{tabular}{ll}
\hline \multicolumn{2}{c}{ Strategies } \\
\hline $\begin{array}{ll}\text { Develop STI programmes and initiatives for developing food } \\
\text { and nutrition security }\end{array}$ & $\begin{array}{l}\text { Develop broadcasting } \\
\text { programmes of } \\
\text { social technologies } \\
\text { focused on the } \\
\text { productive inclusion } \\
\text { of economically } \\
\text { sustainable micro and } \\
\text { small enterprises }\end{array}$ \\
\hline
\end{tabular}

\section{Convergent initiatives}

PROBI02 Project - sustainable system for small producers - (a) Multilateral potential of ornamental, foraging, and medicinal flora; b) fruit trees; c) medicinal and ornamental plants; d) native bees; e) micro organisms

Project oriented towards productive systems, based on goats and sheep and the commercialisation of products to respond Multilateral to the needs of small ruminants. Financed by the World Bank, with technical input by ICARDA, and the participation of Peru, Argentina, and Mexico, together with local non-profit organisations aimed at realising the public interest

BioFortification Project aimed at increasing nutritional value, funded by the Bill and Melinda Gates Foundation, the World Bank Hybrid and development agencies (with support from the HarvestPlus and AgroSalud programmes)

Support programme for rural communities for the transfer of Multilateral technologies associated with cisterns and dams in Paraíba, funded by the World Bank

Programme for fostering the production of milking goats via Bilateral artificial insemination and sanitary management in Santa Maria da Boa Vista, Pernambuco, funded by JICA

Pró-Gavião Project for Community Development in the Rio Gavião Basin, funded by the International Fund for Agricultural Development (IFAD), with lead participation by the Company for Development and Regional Action (CAR) of the Government of the State of Bahia

Project for training, monitoring, deploying and assessing technologies for the Brazilian semi-arid region and family agriculture in the Serra de Dois Irmãos region (Piauí/Bahia), in co-operation with FAO, and with a focus on territorial development

Project aimed at promoting the concept of territorial identities in the semi-arid region, in co-operation with CIRAD and FAO, and including a training programme for the families of young farmers

Multilateral

Multilateral

Hybrid

Source: Compiled by the author, based on field research and ENCTI (2012) 


\section{Final considerations}

This study of convergence and divergence between ENCTI and actual international cooperation reflected in CPATSA initiatives shows that co-operation did conform with STI policy, and worked to advance its goals. However, while the initiatives converged with all these policy goals, they displayed major differences in emphasis. These aspects should be revised, in order to align CPATSA's activities more closely with national STI policy.

Despite this broad positive finding, the study has identified four points of concern. The first is the absence of strategic partnerships with other BRICS and IBSA countries, contradicting explicit policy statements of the national interest. The second is the absence of initiatives for improving the national research system, a clear ENCTI goal.

Brazil also lacks a research system that is strategic and relevant to contemporary reality, which could benefit from a co-operative perspective on the international level. This includes an effective system for forecasting natural disasters in vulnerable areas, also a clearly stated goal in STI policy. Although CPATSA participated in one international initiative in this area with the UNCCD and ESA, it did not produce the anticipated results, and was eventually terminated.

These gaps seem to point to a degree of fragmentation between the macro and micro aspects of international co-operation in S\&T, also revealed in the literature by authors such as Flink and Schreiterer (2010) who corroborate the results of research undertaken by the European Commission (2014) to improve its understanding of international cooperation agreements between the EU and its member states and various other countries. This research highlighted a lack of planning frameworks, duplication, a waste of resources, and a lack of alignment and co-ordination, thereby undermining the potential benefits of co-operation. The EC study also established that international co-operation in S\&T often resulted from individual contacts and linkages between researchers and research organisations, with no government involvement.

The third point of concern is related to the small number of international co-operation initiatives brought in by CPATSA researchers. In fact, this study found that most initiatives in which CPATSA had participated had originated with other Brazilian public bodies, or with Embrapa headquarters in Brasilia. This indicates that CPATSA researchers could have played a more proactive role in searching for opportunities to participate in initiatives undertaken by multilateral bodies or international co-operation agencies, and normally published as 'calls for proposals'. It could even be argued that a more dynamic attitude on the part of these researchers could further advance S\&T in the Brazilian agriculture sector.

This form of mobilisation is increasingly necessary, especially in moments when unfavourable conjunctures, which occur cyclically in Brazilian public sector administration, are likely to result in contractions in investment in the knowledge production sector. By contrast, international co-operation can be a source of relief in such difficult periods. This study has shown that international co-operation initiatives implemented in the semiarid region emerged mainly from Embrapa headquarters, other decentralised units of this organisation, or other government agencies, and were conceived by a minority of research- 
ers and managers. It should not be forgotten that advances across the border of knowledge results from collaboration with scientific communities in countries with high scores on the scientific and technological development index.

The last point of concern, and perhaps the most important one, is the gap between CPATSA and the knowledge it has gained from these initiatives on the one hand, and the productive sector on the other. This is a vital feature of the Brazilian agricultural research system that requires special attention from policy-makers. The lack of post-implementation monitoring prevents an assessment of which government goals were actually achieved, which were only partially achieved, and which were not achieved. In addition, more information about the results of these international initiatives would make it possible to assess whether they had unintended consequences, such as creating relationships of dependency between small farmers, donors and companies; and harmful social and environmental changes that benefit some actors at the expense of others. In this instance, it would be necessary to enquire whether these initiatives continue to meet the government's objectives. These are some of the challenges that need to be addressed in the strategic management of international S\&T co-operation in agriculture in the Brazilian semiarid region.

\section{Notes}

1 This corresponds to a new period in the history of science that started in 1944 with the Manhattan Project, which produced the first atomic bomb, in which research was performed by pools of researchers from various institutions, drawing in resources and structures in ways that had never been seen before (Baiardi 1997).

2 The Centre de Coopération Internationale en Recherche Agronomique pour le Développement (CIRAD); Institut National de Recherche en Agriculture (INRA); and Institut National de Recherche en Agriculture (CGIAR). Stakeholders interviewed included Bernard Mallet, director of both CIRAD and INRA; Francisco J B Reifschneider, former director of the CGIAR; and Osvaldo Coelho, politician active in the region for four decades.

3 In a technical communication, Cruvinel and Martin-Neto adopted the concept of agribusiness as proposed in 1957 by John Davis and Ray Goldberg defined as 'the sum of operations of production and distribution of agricultural supplies, the production operations in agricultural, storage, processing, and distribution units for agricultural products and items produced from them' (EMBRAPA 1999: 1).

4 Centros em Estudos Avançados em Economia Aplicada (CEPEA); Escola Superior de Agricultura Luiz de Queiroz (ESALQ); Universidade de São Paulo (USP). See <http://www.cepea.esalq.usp.br/pib/> [accessed on 1 December 2014].

5 The BRICS alliance comprises the emerging economies of Brazil, Russia, India, China, and South Africa, which constitute a new political-diplomatic entity aimed at fostering multisectoral co-operation among its members. It has been established in the course of seven summits, held between 2008 and 2015.

6 The IBSA Dialogue Forum comprises India, Brazil and South Africa. Established in 2003 it brings together the three multi-ethnic democracies of the developing world, dealing with the three aspects of policy coordination, sectoral co-operation and the IBSA Fund. See <http://www.itamaraty.gov.br/pt-BR/politicaexterna/mecanismos-inter-regionais/3673-forum-de-dialogo-india-brasil-e-africa-do-sul-ibas $>$ [accessed on 1 May 2016].

7 This is particiularly surprising in the case of India, as it was the co-operation between Brazil and India on improving zebu cattle that turned Brazil into the world's largest beef exporter.

8 'A atuação do MCTI na agregação de valor à biodiversidade pautou-se pelo objetivo de ampliar o 
conhecimento científico sobre os ecossistemas brasileiros e a biodiversidade associada, apoiando o desenvolvimento tecnológico e inovação para agregação de valor aos bens e serviços provenientes desse patrimônio natural. O desafio do MCTI, em 2012 foi de planejar, estruturar e iniciar a implantação de estratégias que permitam, simultaneamente, o avanço no conhecimento da biodiversidade e a identificação de novas moléculas, produtos ou processos de efetivo potencial econômico. O objetivo de médio prazo é transformar o Brasil em uma liderança internacional tanto na pesquisa em biodiversidade, como no seu uso sustentável, revertendo parte dos lucros com a comercialização de produtos ou processos derivados de nossa alta diversidade de espécies, na conservação deste gigantesco patrimônio natural' (MCTI 2012:17).

9 Although they avail themselves of knowledge and in many cases technology, innovations are considered non-technological when they relate primarily to models of business, marketing, distribution channels, supply chains, management, urban planning, and transportation logistics (MCTI 2012).

10 'A agropecuária necessita de muita pesquisa em biotecnologia, manejo de solo e práticas que continuem a aumentar a produtividade agrícola e da pecuária de forma compatível com a preservação do patrimônio ambiental. Há uma demanda crescente por alimentos no mundo e o Brasil é o País que mais aumentou o excedente de exportação de alimentos na última década' (MCTI 2011:35).

11 'The green economy, understood as an economy that will promote economic growth on the basis of environmental and productive inclusion, can be the great Brazilian strategic investment' (MCTI 2012).

12 Ordinance No 409 of 15 April 2014, Section 1, No 74, establishing the Brazilian Network of Biological Resource Centres (CRB-Br Network) and its structure under the Ministry of Science, Technology and Innovation (MCTI).

13 CYTED is a platform for promoting and supporting multilateral co-operation in S\&T among Latin American countries.

\section{References}

Baiardi, Amilcar and Maria Clotilde Meirelles Ribeiro. 2011. 'A Cooperação Internacional Norte-Sul na Ciência e na Tecnologia: gênese e evolução'. Caderno. CRH, Salvador, 2 (63): 593-608.

Bazzo, Walter Antonio, Irlan von Linsingen and Luiz Teixeira do Vale Pereira (eds). 2003. Introdução aos Estudos de CTS (Ciência, Tecnologia e Sociedade). Madri: Organização dos Estados Ibero-americanos.

Chaves, Roselene de Queiroz. 2010. Inovatividade no Sistema Brasileiro de Inovação na Agricultura: uma análise baseada na politica de cooperação internacional da Embrapa. PhD Thesis. Universidade Federal do Rio Grande do Sul. Avaliable at: <https://www.lume.ufrgs.br/bitstream/ handle/10183/23973/000743800.pdf? sequence $=1>$ [accessed on 26 July 2012].

Contini, Elisio and Patrick Séchet. 2005. 'Ainda há um longo caminho para a ciência e tecnologia no Brasil'. Revista Brasileira de Pós-Graduação 2 (3): 30-39.

Cruvine, Paulo and Ladislau Martin-Neto. 1999. 'Subsídios para o desenvolvimento do agronegócio brasileiro: o Programa Automação Agropecuária, visão e estratégias'. 4p. Série Embrapa Instrumentação Agropecuária. Comunicado Téc.(32):1- 4. São Carlos: Embrapa Instrumentação Agropecuária.

European Commission. 2014. Basic Principles for Effective International Science, Technology and Innovation Agreements. Luxembourg: Publications Office of the European Union. Edited by Derek Jan Fikkers (Technopolis Group) and Manfred Horvat (Technische Universität Wien). Available at: $<$ https://ec.europa.eu/research/iscp/pdf/publications/Final_Basic_Principles_Science_Tech_Innovation-MainReport.pdf> [accessed on 1 April 2016]. 
Flink, Tim and Ulrich Schreiterer. 2010. 'Science diplomacy at the intersection of S\&T policies and foreign affairs: toward a typology of national approaches'. Oxford Journals. Science and Public Policy 37(9): 665-677.

Foray, Dominique. 2006. L' economia della conoscenza. Bologna: Il Mulino Universale Paperbacks.

Hall, Andrew, Norman Clark, Rasheed Sulaiman, M V K Sivamohan and B Yoganand. 2000. 'New agendas for agricultural research in developing countries: policy analysis and institutional implications'. Knowledge, Technology \& Policy, 13 ()1)1: 70-91. MARch. Available at: < https://core.ac.uk/ download/files/449/12107097.pdf> [accessed on 15 March 2016].

Lundvall, Bengt-Åke. 1997. National Systems and National Styles of Innovation. In SEAT Conference, 'Differences in styles of technological innovation', Manchester, 2-4 September. Available at: http://www.business.aau.dk/ esa/evolution/docmaster/druidstuff/druidthemeC/papers/styles.pdf [accessed on 2 May 2012].

Milani, Carlos R S. 2012. 'Aprendendo com a História: críticas à experiência da Cooperação NorteSul e atuais desafios à Cooperação Sul-Sul'. Caderno CRH, Salvador, 25 (65), May/Aug, 211-231.

Ministério de Ciência, Tecnologia e Inovação, MCTI. 2012. Estratégia Nacional de Ciência, Tecnologia e Inovação 2012-2015: Balanço das Atividades Estruturantes 2011. Brasília: MCTI.

2010. Livro Azul. 4.ed. Conferência Nacional de Ciência Tecnologia e Inovação para o Desenvolvimento Sustentável. Brasília: MCTI.

Mintzberg, Henry. 2004. Ascensão e Queda do Planejamento Estratégico. Porto Alegre: Bookman.

Quiñones, Ainoa. 2013. Impacto de la innovación y la ayuda científico- tecnológica en los países en desarrollo. PhD Thesis. Universidad Complutense de Madrid. Available at: <http://eprints.ucm. es/17847/1/T34118.pdf> [Accessed 23 July 2013].

Quiñones, Ainoa and Sergio Vázquez Tezanos. 2011. Ayuda Oficial al Desarrollo Científico-Tecnológica: Una Evaluación Macroeconómica de la Distribución Geográfica Y Sectorial. Revista de Economía Mundial, 29.

Rezende, Sergio Machado. 2011. 'A evolução da política de C\&T no Brasil'. In Francisco Carlos Teixeira Silva et al. A Finep no Século XXI. Brasília: Financiadora de Estudos e Projetos.

Ribeiro, Maria Clotilde Meirelles. 2015. Cooperação internacional em ciência e tecnologia: uma análise das experiências da Embrapa Semiárido. PhD Thesis. Universidade Federal da Bahia, Escola de Administração, Salvador/Ba.

Riddell, Roger C. 2007. Does Foreign Aid Really Work? New York: Oxford University Press.

Silva, Francisco Carlos Teixeira. 2011. 'O desenvolvimento brasileiro e a formação do Sistema Nacional de Ciência e Tecnologia. In Francisco Carlos Teixeira Silva et al. A Finep no Século XXI. Brasília: Financiadora de Estudos e Projetos.

Skolnikoff, Eugene B. 1994. The Elusive Transformation: Science, Technology, and the Evolution of International Politics. [e-book] Princeton: Princeton University Press. Avalilable at: <http://www. princeton.edu/main/library/> [Acessed 18 April 2015].

Sotillo, José Angel. 2011. El Sistema de Cooperación para el Desarollo: actores, formas y procesos. Madrid: Instituto Universitario de Desarollo y Cooperación (IUDC).

Tribe, Derek E. 1994. Feeding and Greening the World: The Role of International Agricultural Research. Wallingford. International Agricultural Research. 
Troyjo, Marcos Prado. 2003. Tecnologia \& Diplomacia: Desafios da Cooperação Internacional no campo Científico-Tecnológico. São Paulo: Aduaneiras.

\section{About the author}

Maria Clotilde Ribeiro holds a doctorate and a master's degree in business administration from the Federal University of Bahia (Brazil). She also undertook doctoral training at the University of Toronto, and studied systems engineering in France. She is an adjunct professor of the Federal University of Vale do São Francisco (Brazil), a research member of the Laboratory for World Politics Analysis, and participates in an academic co-operation network for training in international management. Working as a consultant, she has coordinated various projects in the public and private sectors, and served as director of a technology company. She has authored Globalization and New Actors: Paradiplomacy of Brazilian Cities (2009). Her research focuses on international co-operation in S\&T, and S\&T\&I in the agriculture sector.

Received on 17 November 2015, and approved for publication on 6 June 2016. 